\title{
Overlooked? Underestimated? Effects of Substrate Curvature on Cell Behavior
}

Citation for published version (APA):

Baptista, D., Teixeira, L., van Blitterswijk, C., Giselbrecht, S., \& Truckenmuller, R. (2019). Overlooked? Underestimated? Effects of Substrate Curvature on Cell Behavior. Trends in Biotechnology, 37(8), 838854. https://doi.org/10.1016/j.tibtech.2019.01.006

Document status and date:

Published: 01/08/2019

DOI:

10.1016/j.tibtech.2019.01.006

Document Version:

Publisher's PDF, also known as Version of record

Document license:

Taverne

Please check the document version of this publication:

- A submitted manuscript is the version of the article upon submission and before peer-review. There can be important differences between the submitted version and the official published version of record.

People interested in the research are advised to contact the author for the final version of the publication, or visit the DOI to the publisher's website.

- The final author version and the galley proof are versions of the publication after peer review.

- The final published version features the final layout of the paper including the volume, issue and page numbers.

Link to publication

\footnotetext{
General rights rights.

- You may freely distribute the URL identifying the publication in the public portal. please follow below link for the End User Agreement:

www.umlib.nl/taverne-license

Take down policy

If you believe that this document breaches copyright please contact us at:

repository@maastrichtuniversity.nl

providing details and we will investigate your claim.
}

Copyright and moral rights for the publications made accessible in the public portal are retained by the authors and/or other copyright owners and it is a condition of accessing publications that users recognise and abide by the legal requirements associated with these

- Users may download and print one copy of any publication from the public portal for the purpose of private study or research.

- You may not further distribute the material or use it for any profit-making activity or commercial gain

If the publication is distributed under the terms of Article $25 \mathrm{fa}$ of the Dutch Copyright Act, indicated by the "Taverne" license above, 


\title{
Overlooked? Underestimated? Effects of Substrate Curvature on Cell Behavior
}

\author{
Danielle Baptista, ${ }^{1}$ Liliana Teixeira, ${ }^{1,2}$ Clemens van Blitterswijk, ${ }^{1}$ Stefan Giselbrecht, ${ }^{1,3}$ and \\ Roman Truckenmüller ${ }^{1,3, \star}$
}

In biological systems, form and function are inherently correlated. Despite this strong interdependence, the biological effect of curvature has been largely overlooked or underestimated, and consequently it has rarely been considered in the design of new cell-material interfaces. This review summarizes current understanding of the interplay between the curvature of a cell substrate and the related morphological and functional cellular response. In this context, we also discuss what is currently known about how, in the process of such a response, cells recognize curvature and accordingly reshape their membrane. Beyond this, we highlight state-of-the-art microtechnologies for engineering curved biomaterials at cell-scale, and describe aspects that impair or improve readouts of the pure effect of curvature on cells.

\section{Physiological Relevance of Curvature}

In living systems, geometric form and biological function are inherently linked together on all scales. The diversity of such systems or organisms is expressed in a plethora of forms or shapes, but with a striking prevalence of one major class of shapes: The outer appearance of organisms is dominated by round(ed) shapes or curved surfaces, a phenomenon which continues inside at interfaces between tissues or at boundaries between tissues and body lumens (or the fluids or air contained therein); curvature also manifests itself under microscopic evaluation (Figure 1, Key Figure). An example of the relationship between curved form and biological or physiological function at a macroscopic level is the biomechanical damping contribution of the double S-shape of the human spine. Concomitantly, there is strong evidence that the loss of original shape is a cause or consequence of a disease. For example in keratoconus, an eye disorder, the curved cornea thins out and bulges like a cone, resulting in blurry and distorted vision. At a microscopic, cellular level, though, the curved form-biological function relationship is still widely unexplored.

Over several decades, numerous studies have shown the influence of cellular- and subcellularscale topography of (flat) culture substrates on cell fate, such as in a landmark paper by Dalby and colleagues [1]. Other substrate properties such as substrate chemistry have been investigated similarly extensively [2]; more recently, confined cell adhesiveness [3,4] and matrix elasticity or stiffness [5] have also been studied. By contrast, far fewer studies have investigated the effect of substrate curvature on cell behavior. Early studies were conducted on glass fibers, as in 1964 when Curtis and Varde cultured chick heart fibroblasts on such substrates [6]. Other studies around that time were performed on glass beads [7] or on rounded grooves/ridges copied into polyvinylchloride plates using stamps originating from modified discs for sound recording [8]. In these studies, the effect of curvature often was not fully considered, or was at least not the main focus of the investigation. In addition to largely overlooking or underestimating the curvature effect on cell behavior for a long time, the lack of available methods

\section{Highlights}

There is increasing evidence that substrate curvature on a (near-)cell scale affects cell fate.

High-resolution rapid prototyping/additive manufacturing technologies including stereolithography, twophoton polymerization (2PP) laser lithography, and digital mirror device-based digital light processing - can create structures with defined, complex (outof-plane) curvature. 2PP technology can create smooth structures or structures with defined superimposed surface roughness, texture, or topography.

Curvature chip technologies are about to drastically ease systematic studies on cell-curvature interactions, and to enable the (re)creation of microanatomically shaped cellular microenvironments in tissues/organs on chips.

These new techniques are expected to change how cell-biomaterial interfaces in vitro and in vivo will be engineered in the future.

${ }^{1}$ Department of Complex Tissue Regeneration, MERLN Institute for Technology-Inspired Regenerative Medicine, Maastricht University, Universiteitssingel 40, 6229 ER Maastricht, The Netherlands ${ }^{2}$ Department of Developmental BioEngineering, Technical Medical Centre, University of Twente, Drienerlolaan 5, 7522 NB Enschede, The Netherlands

${ }^{3}$ These authors contributed equally to this work

*Correspondence:

r.truckenmuller@maastrichtuniversity. $\mathrm{nl}$ (R. Truckenmüller). 
to engineer the required complex substrate geometries in a controlled way might have contributed to the further delay of corresponding studies.

The maximum curvature radius that can still be sensed by a cell stands in relation to the size of the cell and cannot be too different from it. Consequently, substrate engineering must occur somewhere at the milli- or micrometer range, or at a smaller scale. The aforementioned lack of engineering methods can be traced back to the fact that micromachining is based on $\mathbf{2} \mathbf{1} \mathbf{2} \mathbf{D}$ (see Glossary) processes that have their origin in photolithographic patterning processes from the early semiconductor industry. With the advent of new, 3D-capable micro-/nanotechnologies such as two-photon polymerization (2PP) laser lithography (Figure 1), systematic studies screening for the cellular response to substrate curvature of different types at near-cell scales have become possible. This in turn can be expected to boost the development of a next generation of biomedical interfaces on and in devices ranging from biomaterial scaffolds for tissue engineering to microfluidic in vitro tissue or organ model systems for pharmaceutical testing.

The review summarizes current knowledge and understanding of the effect of substrate curvature on cell response. Translating curved substrate geometry to the inherent molecular machinery of the cell as a consequence of mechanosensing and mechanotransduction includes events such as bending of the cell/plasma membrane and induction of cell polarity. We also review the state of the art of microtechnologies for both explicitly and implicitly engineering anatomically or biomimetically curved biomaterials at a microscale or at the cellular level. This condensed and structured information will help the readers to design and conduct their own advanced fundamental cell studies, or to develop and create innovative materials and devices with wide implications in the field of applied biosciences, such as in the areas of tissue engineering and regenerative medicine.

\section{Cell-Substrate Curvature Interaction}

Curvature Recognition and Membrane Reshaping

Although still an unexplored field, cell behavior in 3D matrices is completely different from behavior in 2D/planar substrates of the same material [9]. Moreover, cells can discriminate between planar, convex, and concave surfaces (Figure 1). For example, fibroblasts can differentiate spherical convex substrate curvature up to a curvature diameter of $2 \mathrm{~mm}$, above which they showed responses similar to those for a planar surface [10]. So far, no general dimensional threshold for curvature sensing, such as the ratio between the size of a cell and the diameter of a curved surface, has been determined. This is probably because such a general curvature threshold would depend on (too) many assumed factors such as cell type or superimposed surface topography/roughness of the curved substrate, in each case leading to different results. Depending on cellular and substrate-related factors, cells are able to reshape and adapt to a given curved surface to different extents (Box 1 Figure IA, and Figure 2). Mechanotransduction of cells on convex surfaces is mediated by the BAR (Bin/amphiphysin/Rvs) domain proteins which can recognize and induce a corresponding bending of the cell membrane (Box 1 Figure IC, top). Upon contact of a cell membrane with a convex surface, the BAR domain releases small GTPases and binds to the membrane, inducing curvature [11]. It was found that various effectors of small GTPases participate in cell-cycle regulation and actin dynamics [12,13]. Consequently, these actively regulate proliferation, cell shape, polarity, and locomotion. Thus, it is suggested that convex surfaces have a crucial effect on the cell cycle and the cytoskeleton.

Similarly to convex surfaces, several proteins, such as inverse BAR (I-BAR) domain proteins, have been identified to play a role in mechanotransduction of cells on concave surfaces (Box 1 Figure IC, bottom). Whether the function of I-BAR domain proteins is to sense membrane (and
Glossary

Anisotropic: not/non-isotropic Aspect ratio: of a cell, the ratio between the largest and the smallest diameter of an ellipse fitted around the cell body in an image of the same.

Biomimetic: imitating the functional principle of (an element of) a living object, for example to solve a technical problem.

Concave: the property of a surface or interface being curved inwards.

Convex: the property of being curved outwards; opposite of concave.

Cell/plasma membrane: a semipermeable lipid bilayer separating the inner space of a cell comprising its cytoplasm, cytoskeleton, and organelles from its outer, extracellular (micro) environment.

Cell morphology: the microscopic appearance of a cell and all its structures, for example (concerning) its overall shape and size, and/or the location of its nucleus.

Cytoskeleton: a network of filaments and tubules within the cytoplasm of a cell that, among others, allow it to maintain or change its outer shape and internal organization, and enable cell division and movement.

21/2D: two-and-a-half-dimensional; simple form of three-dimensional (3D) with the third dimension being created from a base area by its projection.

Extracellular matrix (ECM): the non-cellular macromolecular network of cell-secreted fibrous proteins and glycosaminoglycans that provides structural, adhesive, mechanical and biochemical support (signals) to cells. Fluorophore: a molecule that reemits light via fluorescence upon light absorption/excitation

Focal adhesions: large dynamic (transmembrane) protein assemblies through which the cytoskeleton connects to ECM ligands. Focal plane: in light microscopy imaging, the plane through the focus/image point of a microscope that is perpendicular to the axis of the microscope objective.

Ion channels: pores in the cell membrane formed by lining proteins, and that open to allow specific ions to pass through the membrane. 
substrate) curvature or to promote membrane bending is not fully understood. Thereby, these two functions do not need to be mutually exclusive. Both mechanisms may act simultaneously to efficiently sense and support membrane deformation [14]. Possibly, membrane curvature sensing and/or generation is highly dependent on the local concentration of the activated I-BAR domain proteins in the cell. For example, at low concentrations, these proteins might predominantly have a sensory function. Curvature sensing could also lead to opening of mechanogated ion channels [15]. These have been also considered as part of the mechanotransduction machinery of curved surfaces.

Potentially before and instead of other, forced morphological and functional cell responses, when the substrate design allows this, sensing or probing the substrate might lead to escape from a particular curved location rather than to seek for it. In a study by Park and colleagues, the behavior of fibroblasts on concave and convex spherical microstructures made from polydimethylsiloxane (PDMS) was investigated, and fibroblasts were not reluctant to climb on the convex structures. Conversely, the same cells avoided concave surfaces, or entered the microwells briefly $(<10 \mathrm{~h})$ before escaping to the surrounding flat region [16]. However, in a contrasting study, cells of two immortalized salivary gland epithelial cell lines (ductal and acinar) were seeded inside hemispherical craters created from PDMS and coated with poly (lactic-co-glycolic acid) (PLGA) nanofibers where the cells (stayed and) successfully formed curved confluent monolayers lining the concavities [17].

\section{Cell-Morphological Response}

As already has been the case in the historical studies with fibroblasts, cylindrically curved structures such as fibers, tubes, and rounded ridges are often found to induce cell-body elongation and alignment along the longitudinal axis of the structure. Together with a corresponding directional organization of cellular stress fibers, this can be partly assigned to the wellknown contact-guidance phenomenon (Figure 2E) [18,19]. For example, human fetal osteoblasts (HFObs) were reported to orient along microchannels copied into hydroxyapatite from parallel densely packed round metal wires [20]. On day 6 of culture, the strongest nuclear alignment was found for $250 \mu \mathrm{m}$ diameter channels, while on day 18 , the strongest alignment was found for the $100 \mu \mathrm{m}$ diameter channels. The cells in the (less curved) $500 \mu \mathrm{m}$ channels were always less organized. However, Levina and colleagues reported that rat epithelial cells of the IAR-2 line formed straight actin microfilament bundles and (extracellular) fibronectin- or laminin-positive fibrils that were predominantly oriented transversely to the cylinder axis of glass fibers with a diameter of $32 \mu \mathrm{m}$ on which they were cultured [21]. By contrast, the majority of their N-Ras-transformed descendants, IAR-Ras-c4 cells, on acquiring a polarized cell morphology, formed microfilament bundles and extracellular matrix (ECM) fibrils oriented approximately longitudinally to the fiber axes, similarly to normal polarized cells such as fibroblasts. In another study, endothelial colony-forming cells (ECFCs) cultured on electrospun scaffolds with fiber diameters of 5-11 $\mu \mathrm{m}$ were documented to align their cytoskeleton along the fiber axes, whereas human umbilical vein endothelial cells (HUVECs) cultured on the same scaffolds developed a cytoskeleton organized circumferentially around the fibers [22]. Ye and coworkers reported that human brain microvascular endothelial cells (HBMECs) cultured on glass rods with diameters of 10-500 $\mu \mathrm{m}$ 'resist' elongation in response to the curvature of the rod. The authors hypothesize that the phenotype of HBMECs may have evolved to minimize the length of tight junctions per unit length of capillary, and hence minimize paracellular transport into the brain [23]. By contrast, HUVECs this time elongated along the axes of the rods instead of wrapping around them, thereby minimizing the curvature effect. In summary, for anisotropically curved substrate surfaces such as circular cylindrical surfaces, in the first instance,
Isotropic: the characteristic of an object/material or the phenomenon of having identical values of one or more properties in different spatial directions.

Lithography: a method for

transferring an image into a material; for example, in conventional photo-/ UV lithography, by selectively exposing a light-sensitive polymeric 'photoresist' to UV light by means of a locally light-blocking photomask between the UV source and the resist.

Mechanotransduction: processes through which cells sense mechanical signals/stimuli such as substrate topography, elasticity/ stiffness, or stretch by converting them into biochemical signals eliciting specific cellular responses. Micro-/nanotechnology: techniques, processes, skills, tools, etc. used to fabricate structures at the micro-/nanometer scale.

Profilometer: an instrument to measure the topography of a sample such as its surface roughness.

Regenerative medicine: a branch of medicine dealing with methods to regenerate, repair, or replace (by means of tissue engineering, from cells, scaffolds and/or growth factors) diseased, damaged, or lost cells, tissues, or organs.

Scaffold: in tissue engineering, an engineered ECM that is typically in the form of a porous biomaterial.

Tight junctions: strands of transmembrane proteins in a narrow band beneath the apical surface of adjacent epithelial cells where they form a sealing/diffusion barrier controlling the paracellular transport of molecules and blocking the movement of (other) integral membrane proteins to and from the basolateral surface.

Tissue engineering: 'an interdisciplinary field of research that applies both the principles of engineering and the processes and phenomena of the life sciences toward the development of biological substitutes that restore, maintain, or improve tissue function' [97]. 

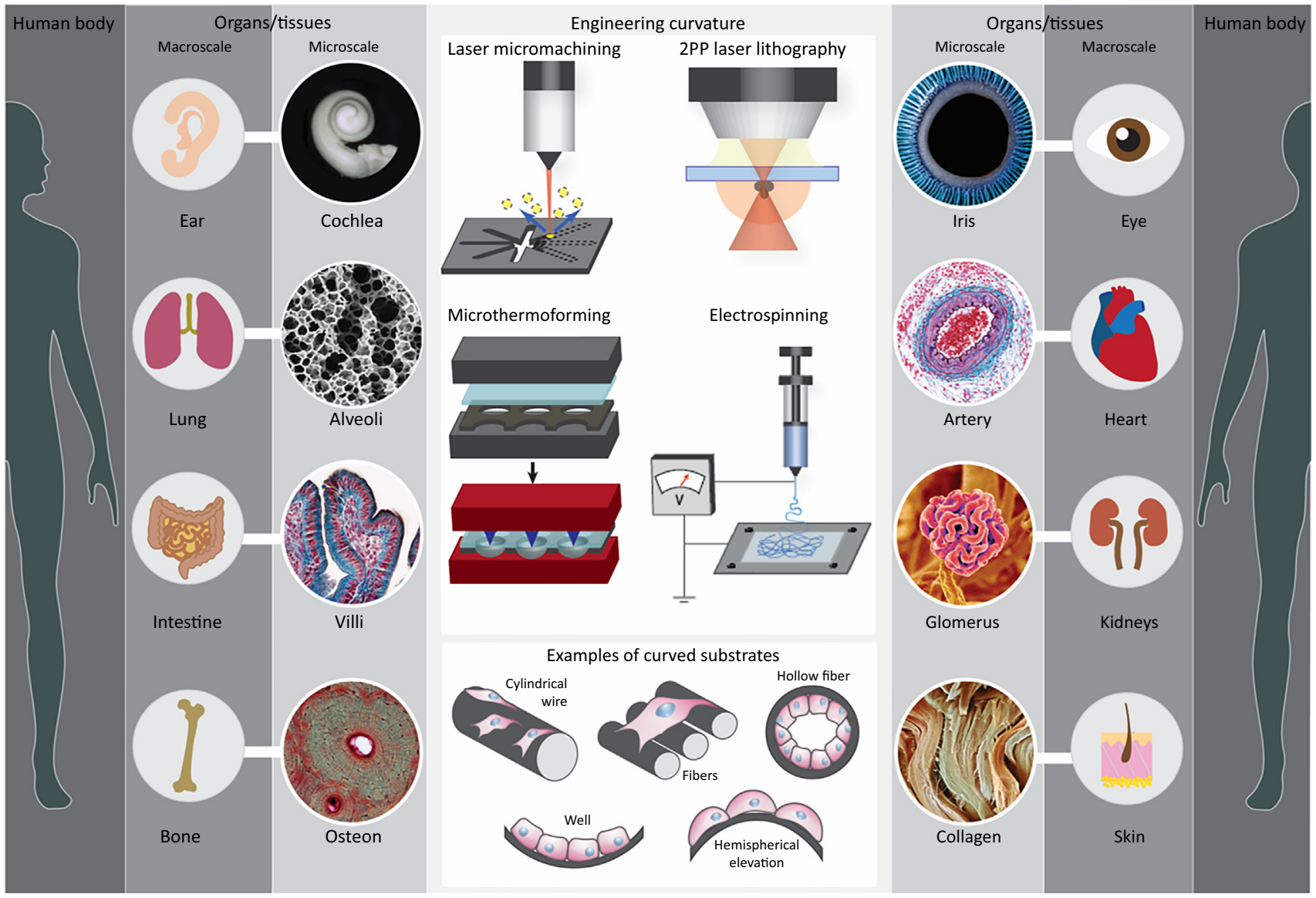

Trends in Biotechnology

Figure 1. Concept figure illustrating (left and right) curvature ubiquitously present at different length scales within the human body, (middle top) state-of-the-art methods for (micro)engineering of microanatomically curved cell substrates, and (middle bottom) examples of curved substrates that can be engineered employing these methodologies. In this review, curvature is discussed as a characteristic of the surface of a cell culture substrate. A curved surface can be concave or convex. An example of convexity is the circular cylindrical surface (with a single curvature axis) of a fiber of an electrospun mesh for tissue engineering. An example of concavity is the (e.g., hemi-)spherical surface (with multiple/infinitely many curvature axes) of a microwell of a thermoformed (porous) film membrane for 3D cell culture. More complex curvatures (with varying signs of the curvature, values for the curvature diameter, and orientations of the curvature axis) are, for example, waves, spirals, and helices such as in case of collagen fibrils and the human cochlea, respectively. (Corrosion cast of) cochlea: Reproduced/adapted, under a Creative Commons Attribution 4.0 International License, from [76]. Alveoli: Reproduced/adapted, with permission of the American Thoracic Society, Copyright @ 2019 American Thoracic Society, from [98]. Osteon: By courtesy of Lutz Slomianka. Abbreviation: 2PP, two-photon polymerization.

anisotropic morphological responses of cells such as their elongation and alignment can be expected and could clearly be demonstrated.

For isotropically curved surfaces such as spherical surfaces, in the absence of directed stimuli such as matrix-mediated or fluidic (shear) forces, and/or substrate-bound or soluble molecular 
(gradient) signals, isotropic or random anisotropic cell responses can be anticipated. However, this does not exclude events such as spontaneous local self-alignment, as found with myoblasts [24]. Morphological differences between cells on less curved, or flat, and more curved substrates can then still be found as scalar variations such as cell area or aspect ratio. For fibroblasts grown on glass balls and plates, for instance, the cell spread area increased with increasing ball diameter and reached its maximum for the flat substrates [10].

\section{Functional Cell Response}

Cells such as epithelial cells, neurons, and migrating cells are naturally polarized due to an asymmetrical distribution of proteins and lipids along the cell-membrane leaflets that impose directionality in their different functions. Polarized cells within an epithelial monolayer exhibit a 'nonadhesive' apical domain, and an 'adhesive' basolateral surface, the latter characterized by interactions between cells and the ECM/basement membrane beneath, and between neighboring cells, such as (by) tight junctions $[25,26]$. Curved surfaces are thought to facilitate the formation of such tight junctions not only by stimulating the production of occludins, functional components of tight junctions [17], but also by inducing a specific localization of distinct actinbased cytoskeletal structures in adherent cells [27].

In neurons, polarity is essential for the propagation of electrical signals through the axon in a unidirectional manner. It was demonstrated that by varying a simple topographical parameter the width of substrate ridges - the orientation and maturation of focal adhesions could be modulated, yielding independent control over the final number and direction of neurite outgrowths $[28,29]$. Thus, it is highly plausible that curvature might influence neuronal polarity, and it may even be considered as a cue in neuronal differentiation [30].

In general, migrating cells (e.g., leukocytes and fibroblasts) use polarity to define structures such as lamellopodia or filopodia, which determine the leading edge of the cell during migration [31]. Lamellopodia can be oriented based on surface-geometric cues, supporting the hypothesis that curvature plays an important role in polarization $[32,33]$.

\section{Box 1. Bending Cell Membranes}

According to McMahon and Gallop, five mechanisms of inducing cell-membrane deformation have been reported (Figure IB) [82]. These mechanisms are based on lipid composition modification (by conical lipids), clustering of shaped (trans)membrane proteins, cytoskeletal scaffolding, protein scaffolding including oligomerization of BAR domain proteins (Figure IC), and protein motif/amphipathic helix insertions. Their function in the process is not independent of each other; it is rather the combinatorial effect of all these mechanisms that leads to drastic changes in cell shape. The cellular membrane has a spontaneous shape (unstressed state) that is characterized by the spontaneous curvature of the membrane bilayer [83]. This curvature depends on the spontaneous curvature of the inner and outer layers of the membrane. The curvature of each layer in turn is governed by the composition (acyl chains and/or headgroups) of the lipids in the layer. The spatial and temporal lipid profile can be analyzed via mass spectrometry [84].

When modifications in the lipid profile are insufficient to bend the membrane, scaffolding membrane proteins such as from the BAR domain protein family are recruited, which deform a membrane by bracing it as a scaffold [85]. These proteins change the membrane curvature by applying pulling and bending forces to the membrane surface. The BAR and F-BAR domain proteins (Figure IC, top and middle) form a banana-shaped dimer of a three-helix coiled coil [86]. The inverse BAR (I-BAR) domain proteins (Figure IC, bottom) are $\alpha$-helical antiparallel dimers which display remote structural homology to BAR and F-BAR domains; however, the I-BAR domain has a zeppelin-shaped structure $[14,87]$. Their natural conformation defines the type of curvature that they are able to recognize and induce. Therefore, BAR domain proteins are involved in sensing convexity and bend the membrane in a convex way, while I-BAR proteins are involved in sensing concavity and force the cellular membrane into a concave shape [11]. 


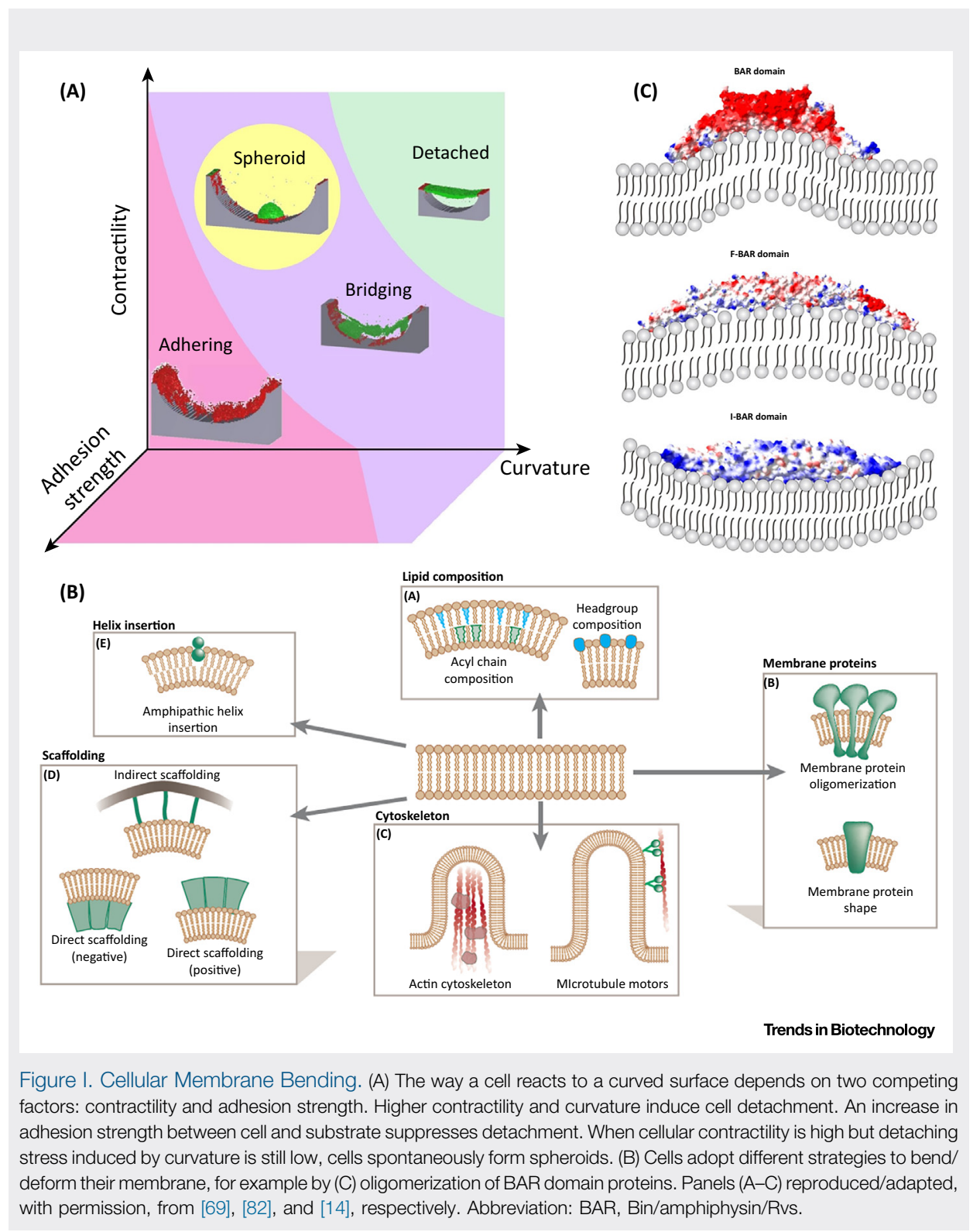

Moreover, by inducing cell polarization, curvature would consequently also affect cell function. For example, mitosis depends on a cell division axis and a specific intracellular organization, which in turn determine the position of future daughter cells [34,35]. Therefore, curvature might be crucial not only for cell fate but also to control symmetric and asymmetric cell division.

Tissue Perspective on Curvature

Notably, in conjunction with curvature, studies focus mostly on single-cell responses and only seldom on collective cell or tissue behavior. The collective behavior of, for example, epithelial cells is essential for lumen development. Xi and colleagues explored the dynamics of monolayers of Madin-Darby canine kidney epithelial cells growing inside microtubes with diameters of 25-250 $\mu \mathrm{m}$, which represent the diameter of distal tubules in kidney nephrons ( $30 \mu \mathrm{m})$ and 

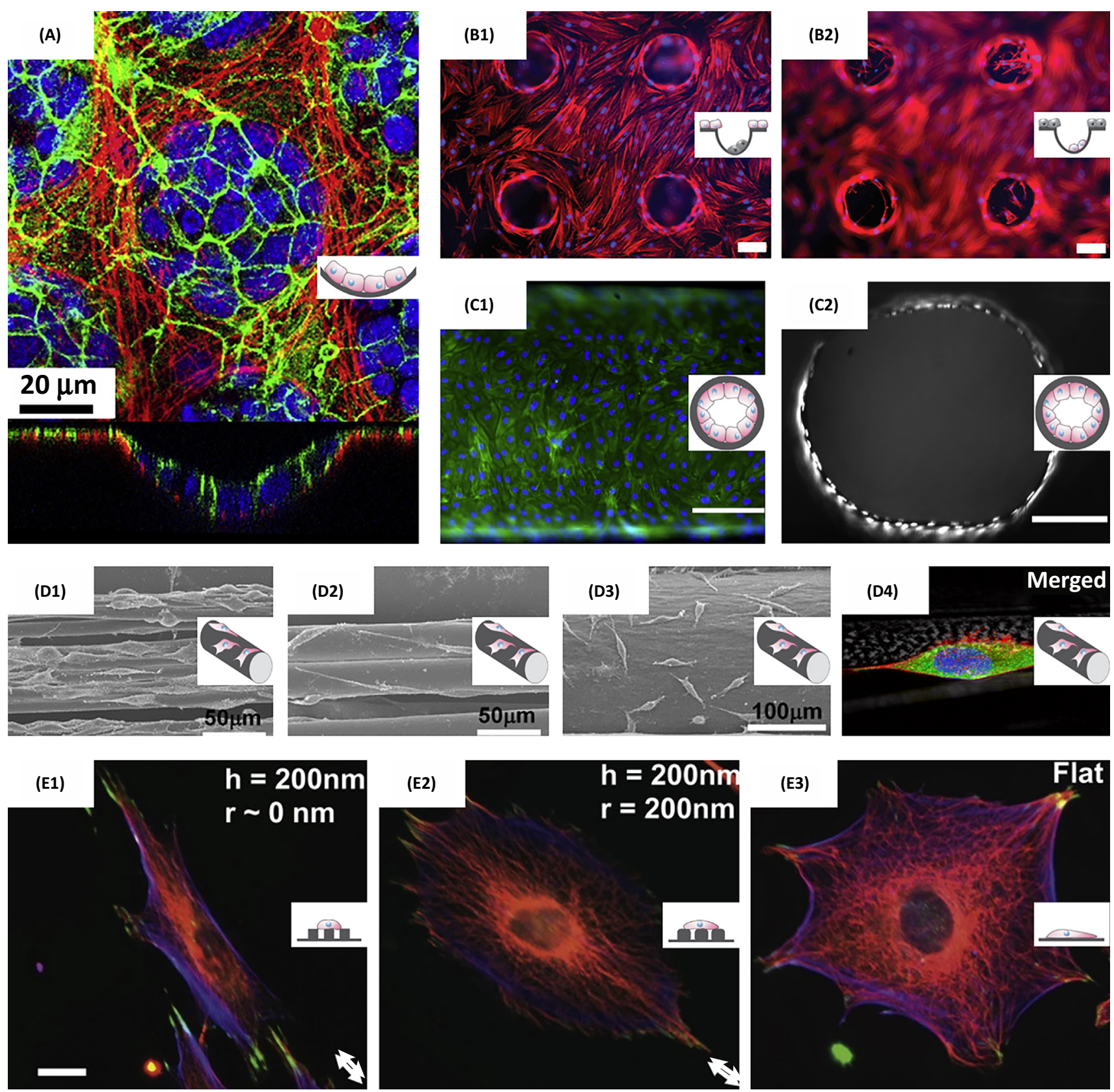

(E3)

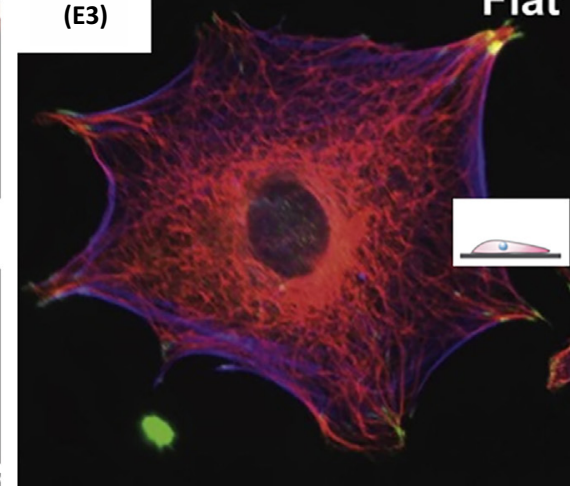

Trends in Biotechnology

Figure 2. Impact of Curvature on Cell Morphology. Cell response to curved surfaces is dependent on cellular and substrate-related factors. Hemispherical cavities can induce different effects: (A) salivary gland cells (SIMS) formed a perfect monolayer in PLGA nanofiber-coated cavities with a diameter of $30 \mu \mathrm{m}$, whereas (B1) human mesenchymal stem/stromal cells (hMSCs) proliferated more on flat PDMS regions (B2) compared with PDMS cavities $200 \mu \mathrm{m}$ in diameter (scale bars, $100 \mu \mathrm{m}$ ). (C1) Primary porcine aortic endothelial cells (PAECs) cultured in $600 \mu \mathrm{m}$ diameter circular cylindrical channels did not show any effect of curvature because cells appear to be randomly organized, (C2) completely lining the channel (scale bars, $200 \mu \mathrm{m}$ ). Regarding convex substrates, there is a clear difference versus the previously mentioned concave examples. Fibroblasts cultured on PLGA fibers showed an inverse relationship between fiber diameter and alignment/elongation. Maximum elongation was registered with fibers of smaller diameters, such as (D1) $10 \mu \mathrm{m}$ and (D2 and D4) $30 \mu \mathrm{m}$, whereas for fibers of (D3) $242 \mu \mathrm{m}$ cell behavior was similar to that on flat surfaces. Fibroblasts were able to discriminate not only between grooved/ridged and flat substrates but also between sharp and rounded/curved ridges. (E1) Cells on sharp grooved substrates elongated and aligned (scale bar, $20 \mu \mathrm{m}$ ), (E3) cells on flat substrates were mostly uniformly spread, and (E2) cells on rounded grooved substrates showed a morphology between those of cells on sharp and flat substrates. Panels (A-E) reproduced/adapted, with permission, from [17], [16], [46], [57], and [19], respectively. Abbreviations: PDMS, polydimethylsiloxane; PLGA, poly(lactic-co-glycolic acid). 
the size of renal papillary collecting ducts (200-300 $\mu \mathrm{m})$ [36]. In smaller microtubes, cells were shown to be taller and arranged in multilayers. Moreover, in the smallest microtubes, tissues could be deduced to have less pronounced forward polarity, and possibly also smaller traction forces, potentially leading to the observed smaller front velocities in these microtubes.

\section{Secondary Curvature Effects}

In addition to the primary, direct surface-topographical effect of curvature on cells, there are also indirect effects. One that also acts through mechanotransduction results from a change in the structure-, shape-, or geometry-dependent (in contrast to material-related) elasticity or stiffness of the substrate. A corresponding example is the wavy and therefore spring-like architecture of fibrous biological and technical substrates such as of collagen fibers in several tissues and of correspondingly engineered/buckled electrospun fibers as their mimics, respectively. Another effect is due to geometrical confinement in conjunction with curvature. Concave surfaces define local volumes by restricting regions in space. Spatial (micro)confinements in turn support cell localization and the maintenance of gradients of molecules, as well as their enrichment and depletion. Intestinal crypts provide a relevant example (Box 2).

\section{Engineering Curvature at the Microscale}

Engineering precisely curved and possibly also smooth structures with the curvature axis/axes parallel to the substrate plane, also referred to as 'out-of-plane curvature', and curvature radii at a scale that can be sensed by the cells, that is, in the milli- and micrometer range (Figure 3E), is challenging. This is also, as already mentioned, because micromachining historically is based on $2 \frac{1}{2} 2 \mathrm{D}$ processes. Fabrication methods for such curved concave and/or convex structures are, among others, mechanical micromachining [37], (photo)lithography followed by isotropic wet etching or dry etching, for example as locally lagged reactive ion etching (Figure 3AE) [38], or followed by melting or thermal reflow of photoresist [17,39], gray-scale/tone lithography [40], laser (micro)machining/ablation [41], $\alpha$-particle radiation with subsequent chemical etching of the latent particle tracks [42], microtunable mold-derived techniques (Figure 3B) [16,43], structuring of concave microwells by squeezing or raking out PDMS precursor of the microcavities followed by forming of a surface-tension induced precursor meniscus [44,45], other soft lithography-based methods [46], molding based on water molds generated by microscale plasma-activated templating [47], ice lithography [48], free-forming variants of microthermoforming of thin polymer films (Figure 3C) [49], stereolithography and 2PP laser lithography [50] (Table 1). Microthermoforming allows the creation of cell substrates combining, for example, curvature and micro-/nanotopographies [51,52] or (bio)chemical micropatterns [53]. Further, it enables the creation of microanatomically curved porous substrates for 3D epithelial and/or endothelial barrier studies $[54,55]$.

Cylindrical curved structures for cell studies can be also provided by, for example, (aligned) electrospun fibers [56,57], melt-extruded fibers/filaments [58], (pulled) glass fibers/wires [59] or (porous) hollow fiber membranes (Figure 3D) [60], and hemispherical structures by spheres or

Box 2. Curvature Confinement of Intestinal Crypts

The configuration of intestinal crypts enables the accumulation of factors mandatory for maintaining the balance between proliferation and differentiation [88]. Intestinal homeostasis is sustained by crypt base columnar stem cells that occupy the crypt floor together with Paneth cells. The pluripotency and proliferation of these stem cells are maintained by Wnt cues supplied by the Paneth cells and subepithelial myofibroblasts that also populate the crypt floor [89]. As the progenitors further ascend the crypt, mesenchyme-derived bone morphogenetic protein (BMP) signaling promotes their differentiation. Without this cavity-like spatial conformation, it would not be possible to maintain gradients of Wnt and BMP cues, which in turn are necessary for the maintenance of the cellular architecture of the crypts. 


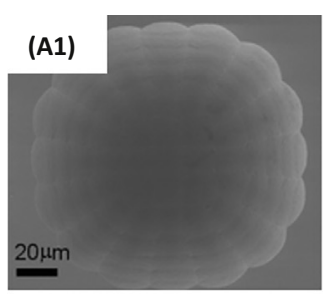

$151 \mu \mathrm{m}$

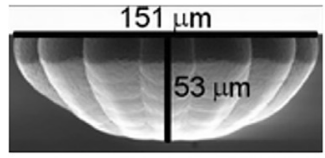

(A2)
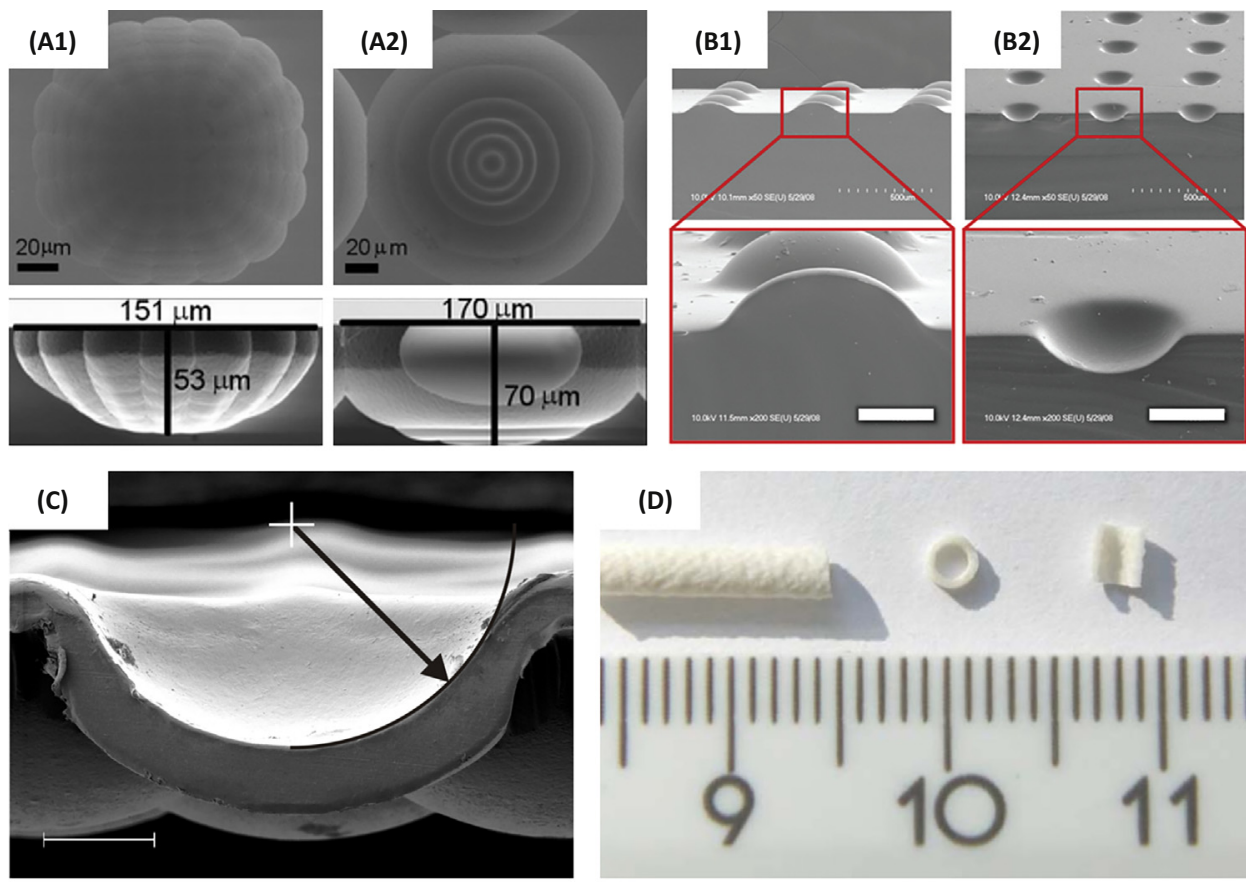

(D)

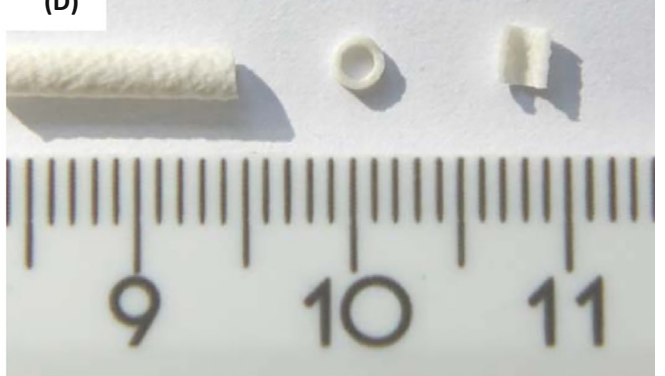

(E) $100 \mu \mathrm{m}$

$10 \mu \mathrm{m}$

$1 \mu \mathrm{m}$

$100 \mathrm{~nm}$

$10 \mathrm{~nm}$

$1 \mathrm{~nm}$

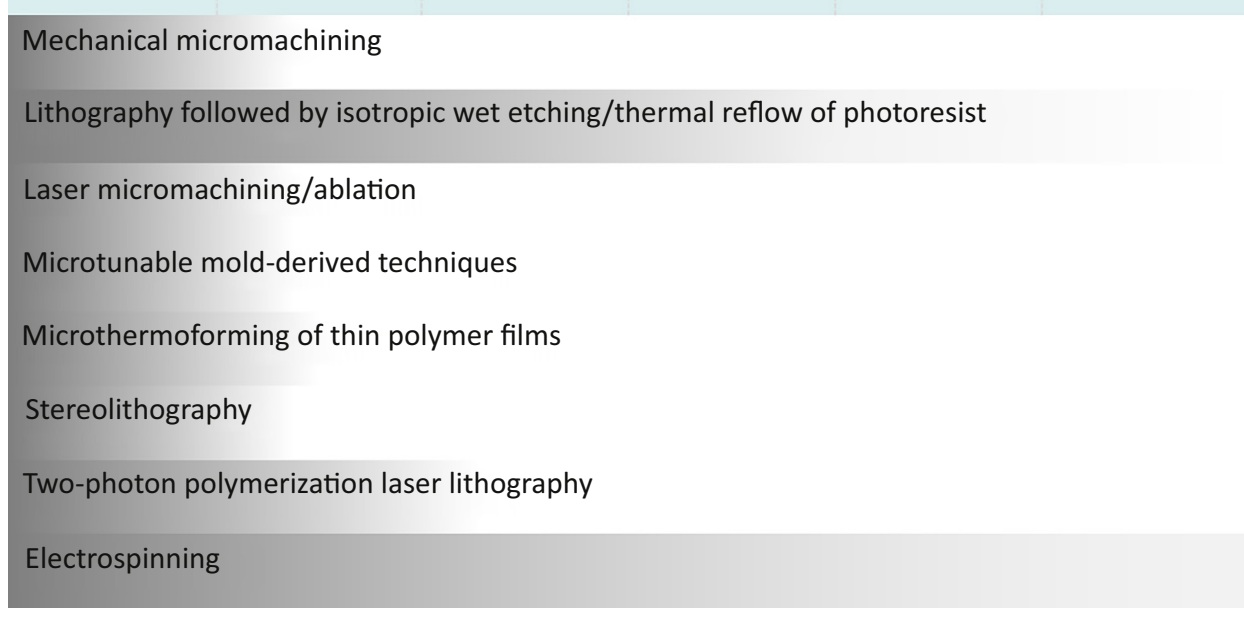

Trends in Biotechnology

Figure 3. Examples of Engineered Curved Cell Substrates. Concave spherical microstructures with superimposed (A1) star-shaped/radial and (A2) circular-concentric patterns fabricated by photolithography followed by locally lagged reactive ion etching. (B1) Concave and (B2) convex structures fabricated by microtunable mold-derived techniques (scale bars, $100 \mu \mathrm{m}$ ). (C) Concave (and at the same time convex) structures fabricated by microthermoforming. (D) Hollow-fiber membrane fabricated by polymer melt extrusion and phase inversion including supercritical carbon dioxide (images include cross-sections of structures). (E) The smallest curvature radius that the individual methods can achieve depends on many factors, such as if the curved structures are explicitly/directly machined or the result of an implicit/indirect effect, or how precise and potentially smooth the structures must be. The radii range from a few tens of micrometers, for example for mechanical micromachining using ball nose end mills, to the subnanometer range for electrospinning [77]. It is debatable, however, whether curvature radii below a threshold at a subcellular scale, probably in the low-micrometer or high-

(Figure legend continued on the bottom of the next page.) 
beads [61], directly or after copying them. Another technique to provide curved artificial cellular microenvironments in the form of hollow cylindrical structures is by on-chip thin-film devices that self-assemble from nanofilms which are prestrained and roll up after releasing them [62]. The film tube diameter can be adjusted by 'strain engineering'.

In contrast to the above structures, structures with the curvature axis perpendicular to the substrate plane can be microengineered comparatively easily, for example by SU-8 UV-/ photolithography or by lithography and subsequent (anisotropic) deep reactive ion etching. However, without special measures, some cells in such laterally curved cylindrical structures might additionally or even exclusively interact with the flat base or bottom of the structure, for example by being confined by or adhering to it. This might in turn result in mixed, falsified readouts (see Reading Out the Impact of Curvature on Cells).

The curved structures described above can partly be directly applied in cell studies, or used as molds to - directly or after an intermediate copying step - copy them into other, biocompatible materials by casting, replica molding, hot embossing, soft embossing, etc. In addition, the limitation of the one or the other technique to only concave or convex structures can be circumvented by copying into the respective other/opposite structure $[46,63]$.

The characterization of microscale curvature has been facilitated in recent years with the availability of a new generation of surface-metrological tools. The latest confocal laser scanning microscopy and partly also white-light interferometry equipment allows measurement of the dimensions and roughness of curved microstructures by meanwhile providing sufficient lateral resolution and capacity to measure along steeper flanks. These optical, noncontact profilometers complement classical tools such as atomic force microscopy and (semi-quantitative) scanning electron microscopy (SEM).

\section{Culturing Cells on Curved Substrates}

When culturing cells on curved substrates and reading out the impact of these surfaces on the cells, several challenges are encountered. These start with the inoculation of the cells. In case of, for example, arrayed spherical wells, as a result of gravity seeding, in addition to their horizontal flat surroundings, the cells first mainly land and concentrate in the deepest part of the wells. A similar nonuniform cell distribution at the beginning of the culture, with very few cells on the inclined parts of the curved surface areas, results from seeding on spherical elevations. When in spherical cavities aiming for the controlled formation of closed epithelial or endothelial monolayers lining the cavities (rather than for undefined 3D cell aggregates/aggregation), the initial substrate-area cell seeding density plays a crucial role. In hollow-fiber membranes or in microfluidic channels with a circular cross-section, depending on the specific setup, after infusion of the cell suspension, a more uniform covering with cells along the main axis of the lumens or their circumference can be achieved by rocking the luminal substrate [64] or rotating it [46].

During subsequent culture, individual cells adhering to curved surfaces in low areal densities experience high degrees of freedom in terms of morphological and positional changes. The corresponding cell responses include distinct cytoskeletal arrangements/organization [61,65] and migration, also on gradient curvature [66] and exactly due to such gradients [67]. If the substrate design allows so, for example in the case of spherical pits in otherwise planar

nanometer range, would change a study on substrate curvature into one on rounded surface-topographical features. An example of such a rounded subcellular surface topography can be found in Figure 2E1-3 and the last row of Table 1. Panels (A-D) reproduced/adapted, with permission, from [38], [16], [52], and [60], respectively. 
Table 1. Survey of Studies on Cell-curvature Interaction

\begin{tabular}{|c|c|c|c|c|}
\hline $\begin{array}{l}\text { Substrate geometries } \\
\text { and dimensions }\end{array}$ & Cell types & Materials and methods & Readouts & Refs \\
\hline \multicolumn{5}{|l|}{ Concave } \\
\hline $\begin{array}{l}\text { Hemispherical channels; } \\
\text { diameter } 100-500 \mu \mathrm{m}\end{array}$ & Human fetal osteoblasts (hFOBs) & $\begin{array}{l}\text { Hydroxyapatite slurry cast over } \\
\text { densely packed stainless steel } \\
\text { wires, dried, demolded, and } \\
\text { sintered }\end{array}$ & $\begin{array}{l}\text { DNA assay, GPCR (RUNX2, } \\
\text { osteopontin, ALP, DMP1, Col-I), } \\
\text { cell orientation, elastic modulus and } \\
\text { hardness of secreted ECM }\end{array}$ & [20] \\
\hline $\begin{array}{l}\text { Roughly spherical wells; } \\
\text { radius } 100 \mu \mathrm{m}\end{array}$ & C2C12 mouse pre-myoblasts & $\begin{array}{l}\text { Poly(lactic acid) films thermally } \\
\text { imprinted and thermoformed }\end{array}$ & Cell alignment/orientation & {$[52]$} \\
\hline $\begin{array}{l}\text { Pits; opening diameter } \\
50.7 \mu \mathrm{m} \text {, depth } 18.8 \mu \mathrm{m}\end{array}$ & HeLa cervical cancer epithelial cells & $\begin{array}{l}\text { Poly(allyl diglycol carbonate) films } \\
\text { irradiated with } \alpha \text {-particles and } \\
\text { chemically etched }\end{array}$ & Microtubule growth and movement & [42] \\
\hline $\begin{array}{l}\text { Circular cross-section } \\
\text { channels; diameter 40- } \\
100 \mu \mathrm{m}\end{array}$ & $\begin{array}{l}\text { Porcine aortic endothelial cells } \\
\text { (PAECs) }\end{array}$ & $\begin{array}{l}\text { Polymerization of dissolved silicone } \\
\text { oligomer around coaxial gas stream } \\
\text { in rectangular-cross-section PDMS } \\
\text { microchannels }\end{array}$ & $\begin{array}{l}\text { Nuclei and filamentous actin } \\
\text { localization }\end{array}$ & [46] \\
\hline $\begin{array}{l}\text { Half-channels of constant } \\
\text { radius; radius } 10-30 \mu \mathrm{m}\end{array}$ & $\begin{array}{l}\text { Human umbilical vein endothelial } \\
\text { cells (HUVECs) }\end{array}$ & $\begin{array}{l}\text { Glass microscope slides etched } \\
\text { following photolithography }\end{array}$ & $\begin{array}{l}\text { Cell area, F-actin stress fiber } \\
\text { number and alignment/orientation, } \\
\text { response to histamine }\end{array}$ & [78] \\
\hline $\begin{array}{l}\text { Circular channels; } \\
\text { diameter } 1-2 \mathrm{~mm}\end{array}$ & МСЗТЗ-E1 mouse pre-osteoblasts & $\begin{array}{l}\text { Hydroxyapatite slurry filled in wax } \\
\text { mold, dried and, after wax removal, } \\
\text { sintered }\end{array}$ & $\begin{array}{l}\text { Actin stress fiber alignment/ } \\
\text { orientation, tissue area, } \mathrm{pO}_{2}\end{array}$ & [79] \\
\hline \multicolumn{5}{|l|}{ Convex } \\
\hline $\begin{array}{l}\text { Wires (circular cross } \\
\text { section); radius 1-85 } \mu \mathrm{m}\end{array}$ & $\begin{array}{l}\text { Madin-Darby canine kidney } \\
\text { (MDCK) epithelial cells, NIH/3T3 } \\
\text { mouse embryonic fibroblasts, } \\
\text { human retinal pigment epithelial } \\
\text { (RPE-1) cells }\end{array}$ & $\begin{array}{l}\text { Borosilicate glass capillaries heated } \\
\text { and pulled }\end{array}$ & $\begin{array}{l}\text { Actin alignment/orientation, focal } \\
\text { adhesion number/density, stress } \\
\text { fiber/actin cable retraction }\end{array}$ & [59] \\
\hline $\begin{array}{l}\text { Fibers (circular cross- } \\
\text { section); diameter } \\
9-63 \mu \mathrm{m}\end{array}$ & Primary rat Schwann cells & Glass fibers tapered & Cell motility/migration speed & [80] \\
\hline $\begin{array}{l}\text { Filaments (circular cross- } \\
\text { section); diameter } \\
35-500 \mu \mathrm{m}\end{array}$ & Dorsal root ganglia (DRGs) & $\begin{array}{l}\text { Polypropylene substrates melt- } \\
\text { extruded into filaments }\end{array}$ & $\begin{array}{l}\text { Neurite outgrowth direction and } \\
\text { alignment }\end{array}$ & [58] \\
\hline $\begin{array}{l}\text { Balls/beads; diameter } \\
\text { 5-2000 } \mu \mathrm{m}\end{array}$ & $\begin{array}{l}\mathrm{NIH} / 3 \mathrm{~T} 3 \text { mouse embryonic } \\
\text { fibroblasts }\end{array}$ & $\begin{array}{l}\text { Glass balls embedded in } \\
\text { polyacrylamide gels }\end{array}$ & $\begin{array}{l}\text { Cell spread area attachment rate, } \\
\text { and migration speed }\end{array}$ & [10] \\
\hline $\begin{array}{l}\text { Balls/beads; diameter } \\
5-4000 \mu \mathrm{m}\end{array}$ & $\begin{array}{l}\text { Human mesenchymal stem/ } \\
\text { stromal cells (hMSCs) }\end{array}$ & $\begin{array}{l}\text { Glass balls embedded in } \\
\text { polyacrylamide gels }\end{array}$ & $\begin{array}{l}\text { Lamellipodium number, cell length, } \\
\text { width, aspect ratio, and spread } \\
\text { area, qPCR (PPARG) }\end{array}$ & [61] \\
\hline $\begin{array}{l}\text { Fibers (circular cross- } \\
\text { section); diameter } 32 \mu \mathrm{m}\end{array}$ & $\begin{array}{l}\text { IAR-2 and IAR-Ras-c4 rat liver } \\
\text { epithelial cells }\end{array}$ & Fused quartz (glass) fibers & $\begin{array}{l}\text { Actin microfilament bundle } \\
\text { alignment/orientation, focal contact } \\
\text { localization }\end{array}$ & [21] \\
\hline Fibers; radius $12-25 \mu \mathrm{m}$ & $\begin{array}{l}\text { Mouse embryonic fibroblasts } \\
\text { (MEFs), L mouse fibroblasts, IAR- } \\
20 \text { and IAR-6-1 rat liver epithelial } \\
\text { cells, fetal bovine tracheal (FBT) } \\
\text { epithelial cells }\end{array}$ & Fused quartz fibers & $\begin{array}{l}\text { Cell area, shape (dispersion and } \\
\text { elongation), and alignment/ } \\
\text { orientation }\end{array}$ & [81] \\
\hline $\begin{array}{l}\text { Spherical bumps; } \\
\text { diameter 200-300 } \mu \mathrm{m} \text {; } \\
\text { height 50-150 } \mu \mathrm{m}\end{array}$ & L929 mouse fibroblasts, hMSCs & $\begin{array}{l}\text { PDMS structured by microtunable } \\
\text { mold-derived techniques }\end{array}$ & $\begin{array}{l}\text { Cell movement, velocity, and } \\
\text { (spatial) distribution }\end{array}$ & [16] \\
\hline
\end{tabular}


Table 1. (continued)

\begin{tabular}{|l|l|l|l|}
\hline $\begin{array}{l}\text { Substrate geometries } \\
\text { and dimensions }\end{array}$ & Cell types & Materials and methods & Readouts \\
\hline $\begin{array}{l}\text { Rounded ridges; radius } \\
<10-400 \mathrm{~nm}\end{array}$ & $\begin{array}{l}\text { Mouse embryonic fibroblasts } \\
\text { (MEFs) }\end{array}$ & $\begin{array}{l}\text { Silicon dioxide chemical vapor- } \\
\text { deposited following } \\
\text { photolithography and reactive ion } \\
\text { etching of fused silica }\end{array}$ & $\begin{array}{l}\text { Cell spread area and aspect/ } \\
\text { anisotropy ratio, focal adhesion and } \\
\text { cytoskeletal alignment }\end{array}$ \\
\hline
\end{tabular}

surroundings, migration can even lead to avoidance of curved areas by moving out of them or not into them [16]. An individual fiber, wire, or hollow fiber obviously does not allow a cell to escape from it, and therefore permanently exposes the cell to the curvature. In contrast to low-cell-density regimens, dense, tissue-like cellular arrangements can reveal collective responses such as cell-sheet-internal cellular elongation and orientation [68]. Another challenge to manage on concave substrates is the balance between substrate curvature, cellular contractility within a tissue adhering to the substrate under particular culture conditions, and ECM-mediated cell-substrate adhesion strength. In case of too small curvature radii, too high contractile forces or too low adhesive strength, cell/tissue sheets partly or fully detach from the curved substrate [69]. The cells or their protrusions can also rupture as a consequence of sample preparation procedures for fluorescence microscopy or SEM, imposing (mechanical) stress on cells such as through their fixation, dehydration, or drying.

\section{Reading Out the Impact of Curvature on Cells}

Assessing the response of cells to curvature (Table 1) can be challenging mainly because of a lack of suitable readouts and biased interpretations of the data. Usually, researchers rely on cell-morphological readouts based on fluorescence labeling to evaluate cell area and shape, cell adhesion to the substrate (e.g., the formation of focal adhesions), cell-to-cell contact (e.g.,

\section{Box 3. Curvature as a YAP/TAZ Regulator}

Hippo signaling is known to modulate cell proliferation, differentiation, growth, and death, and for many years was considered to be the main element in YAP/TAZ regulation in tissues [90]. Recent findings also suggest physical and mechanical cues as important determinants in YAP/TAZ activity, thereby linking these transcription factors with mechanotransduction (Figure IA) [91]. Researchers found that YAP/TAZ activity is regulated by (extracellular) matrix elasticity/stiffness and cell shape [92]. In a corresponding study, mammary epithelial cells (MECs) were cultured on fibronectin-coated acrylamide hydrogels of varying stiffness (elastic modulus ranging from 0.7 to $40 \mathrm{kPa}$ ) and human lung microvascular endothelial cells (HMVECs) on micropatterned fibronectin 'islands' of defined sizes $(10$ 000, 2025, 1024 , and $300 \mu \mathrm{m}^{2}$ ) [93]. The results indicated that in different cellular models cells read matrix elasticity, cell shape, and cytoskeletal forces via levels of YAP/TAZ activity.

As described before, during mechanotransduction on convex structures (Figure IB), BAR domain proteins release small GTPases (Rac, Rho, and CDC42). In the cytoplasm, they remain available for new interactions. Rho molecules play an important role in YAP/TAZ regulation. Moreover, there is evidence that Rho molecules act in conjunction with the actomyosin cytoskeleton in parallel to the NF2/Hippo/LATS pathway [92]. Rho proteins inhibit LATS1/2 by canceling its transcriptional repression of YAP/TAZ. In this way, YAP/TAZ can be transcriptionally activated, inducing proliferation (epithelial and endothelial cells) [93]. Consequently, it is possible that convex structures act as YAP/TAZ transcription activators.

Zona occludens 2 (ZO-2), a protein predominantly found in tight junctions, was also reported to interact with YAP/TAZ via PDZ binding [94,95]. Because some studies reported that concave surfaces stimulate tight junction formation [17], a link between concave sensing and YAP/TAZ activity is also possible (Figure IC). In this case, tight junctions function as traps for YAP/TAZ, preventing them from inducing transcription. In accordance with some publications, this would lead to proteosomal degradation which, in turn, would favor apoptosis and growth arrest [96]. 


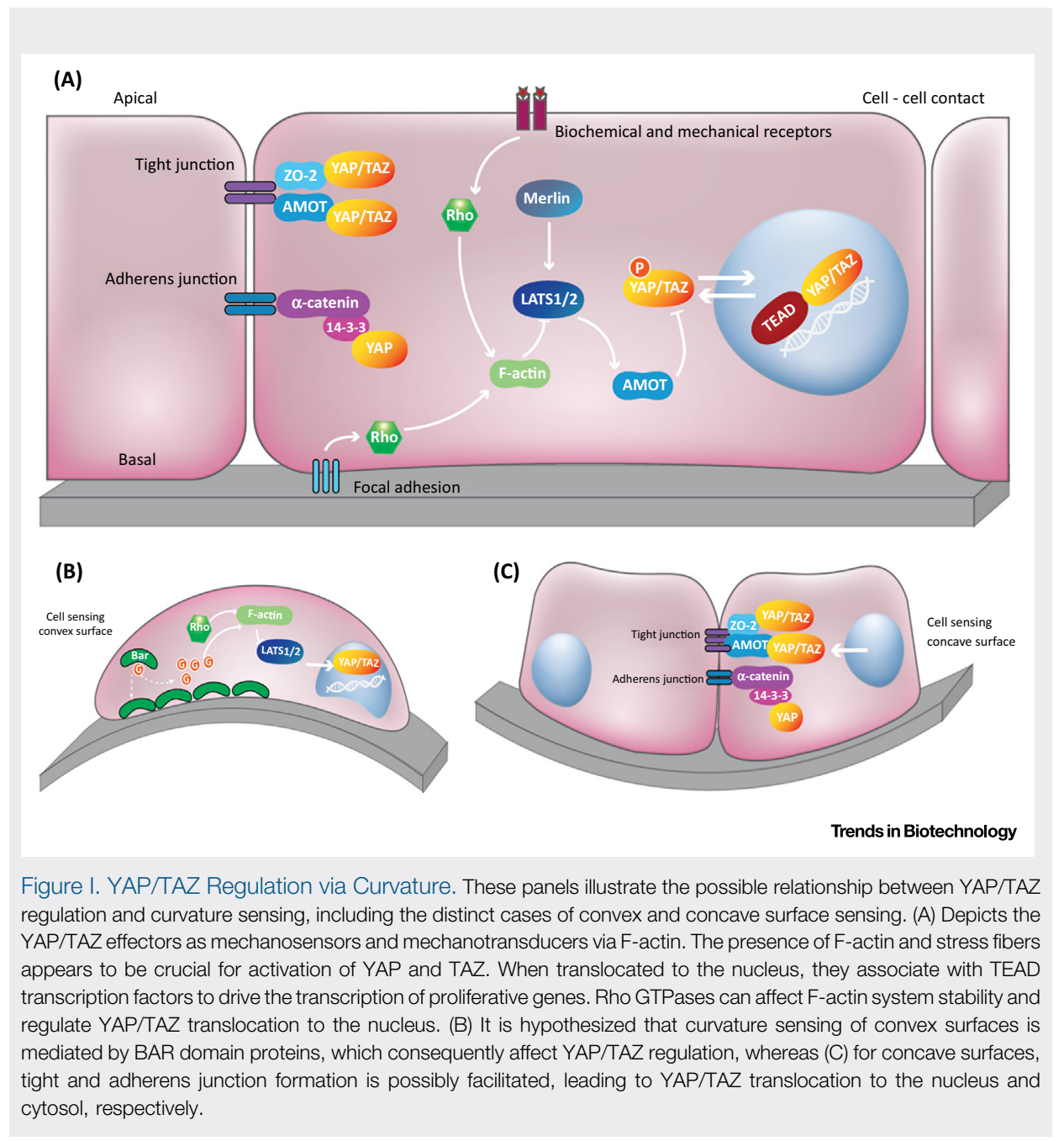

tight junction formation), etc. Although morphological assessment via fluorescence microscopy is accessible and spatially selective, analysis of, for example, cell shape based on microscope images encounters obstacles when curved substrate surfaces are involved. Compared with the straightforward imaging on flat surfaces, conventional microscopes face difficulties in obtaining reliable information from substrates that incorporate curvature including steeper flanks. In general, the incident light used in wide-field microscopy effectively excites all stained material in the $z$ axis, such that the image from a specific $x y$ focal plane is obscured by out-of-plane light. This is exacerbated in the case of curved substrates. Furthermore, substrate curvature causes the incident light to meet the air-substrate interface at an angle, and refractive index differences at this interface wreak havoc on the actual light path. This leads to further nonspecific vertical excitation and ultimately results in distorted images. These issues can be partly overcome by confocal or multiphoton microscopy, which enable more localized excitation of the sample and therefore a more accurate image $[17,70]$.

The use of reporter cell lines can also be of great help if cells are transfected with mechanorelated reporter gene constructs conjugated with fluorophores, enabling more specific 
readouts and live mechanotransduction studies [71]. A Hippo pathway TEAD reporter MCF7 recombinant cell line would be a powerful tool to further investigate the effect of curvature on YAP (Yes-associated protein)/TAZ (transcriptional coactivator with PDZ domain) regulation (Box 3) because basal unphosphorylated YAP/TAZ remains in the nucleus where they interact with TEAD transcriptional factors and induce the constitutive expression of the luciferase reporter [72].

Furthermore, morphological readouts are seldom complemented with biochemical assays. The latter, despite being more insightful, are typically not spatially selective because they are based on cell lysates or culture medium samples. Often, medium samples cannot be related only to a particular curved region of interest because they also stem from its non- or differently curved surroundings. Cells can in principle be harvested only from specific curved regions, but this requires a tool such as for laser dissection. Even this technique cannot prevent mixed readouts as a result of crosstalk between cells from differently curved regions. Therefore, flat or differently curved surroundings should be kept to a minimum. Generally, to prevent biased cell responses by erroneously averaging or influencing them, readout selection should be optimized together with substrate design.

\section{Concluding Remarks and Future Directions}

The effect of substrate curvature on cell behavior is clearly a complex topic. At the same time, it is probably of crucial importance in, for example, tissue regeneration and pharmaceutical testing. Against this background, the relevance of substrate curvature has potentially not been given sufficient attention to date.

However, this is about to change. An increasing number of tools have been made available that allow the fabrication of curved structures at the microscale, also outside clean rooms and without dedicated, expensive microfabrication equipment. This in turn allows more systematic and precise studies of the effects of curvature on cells and miniaturization of the corresponding assays. Miniaturization also permits, among others, higher throughput and lower consumption of biologics. This relationship was already taken advantage of in conjunction with similar platforms to study other substrate properties such as surface topography, for example together with automated microscopic image acquisition, image (post)processing, and data analysis [73]. In this sense, a 'curvature chip' in the form of a microarrayed library of curved features of different types, sizes, etc. for high-throughput screening of cell-substrate curvature interaction is a logical development. The first steps in this direction have been already taken $[16,74,75]$. The described developments are expected to lead to more realistic, bioinspired designs where curvature is translated from native tissues to, for example, cell-receiving substrates in corresponding chip-based in vitro models or bioartificial organ support systems.

So far, the vast majority of studies have focused on individual cells or correspondingly low areal cell densities, which of course facilitates the investigation of (single-)cell-curvature interactions. Only very few studies have addressed cell-cell interaction in response to substrate curvature. However, this tissue perspective on curvature is essential to understand how curvature impacts, for example, on the function of human epithelial or endothelial barriers such as in the lung, intestine, and kidney.

Better understanding the role of substrate curvature could change the way that cell-material interfaces are engineered in the future (see Outstanding Questions). Curvature might be manipulated as an instructive parameter to steer cell behavior, for example to control proliferation rates, apoptotic events, commitment into specific lineages during differentiation, or
Outstanding Questions

When on curved surfaces do we (predominantly) deal with curvature impact, when with (other) topographical effects such as contact guidance, and when with a combination of them?

Does a specific cell type under always the same boundary/culture conditions on a substrate with continuously merging types and degrees of curvature in vitro 'look' within a particular surrounding area always for a similar position and orientation on such a curved landscape? If so, does this correspond to the curvature of the in vivo microenvironment of that cell type?

In which cases are the higher efforts for (microfluidic) organ-on-chip models including advanced, curved cell substrates justified over their conventional 2D counterparts, for example concerning $3 D$ substrate preparation or 3D imaging, and in which cases not?

How will new insights into cell-curvature interaction influence the design of inherently curved fiber-based tissue engineering scaffolds such as from electrospinning or $3 \mathrm{D}$ fiber deposition? 
polarity. Knowledge about the corresponding underlying mechanisms could then be employed to design a next generation of medical implants and beyond. Future applications of curved biointerfaces in vitro and in vivo seem to be nearly endless, as is the overwhelming occurrence of curvature in our bodies and our living environment.

\section{Acknowledgments}

D.B. acknowledges financial support by the Dutch Longfonds (project Microengineered $3 \mathrm{D}$ analogues of alveolar tissue for lung regeneration; grant 6.1.14.010), L.T. by the EU Horizon 2020 European Research Council Advanced Grant (project ORCHESTRATE - Building complex life through self-organization: from organ to organism; ID 694801), and C.v.B., S.G., and R.T. by the Province Limburg (program Limburg INvesteert in haar Kenniseconomie/LINK). The authors acknowledge Dr Paul Wieringa, MERLN Institute, for his support in preparing the first paragraph of the section 'Reading Out the Impact of Curvature on Cells'.

\section{References}

1. Dalby, M.J. et al. (2007) The control of human mesenchymal cell differentiation using nanoscale symmetry and disorder. Nat. Mater. 6, 997-1003

2. Anderson, D.G. et al. (2004) Nanoliter-scale synthesis of arrayed biomaterials and application to human embryonic stem cells. Nat. Biotechnol. 22, 863-866

3. Chen, C.S. et al. (1997) Geometric control of cell life and death. Science, 276, 1425-1428

4. McBeath, R. etal. (2004) Cell shape, cytoskeletal tension, and RhoA regulate stem cell lineage commitment. Dev. Cell, 6, 483-495

5. Discher, D.E. (2005) Tissue cells feel and respond to the stiffness of their substrate. Science, 310, 1139-1143

6. Curtis, A.S.G. and Varde, M. (1964) Control of cell behavior: topological factors. J. Natl. Cancer Inst. 33, 15-26

7. Maroudas, N.G. (1972) Anchorage dependence: correlation between amount of growth and diameter of bead, for single cells grown on individual glass beads. Exp. Cell Res. 74, 337-342

8. Rovensky, Y.A. et al. (1971) Behaviour of fibroblast-like cells on grooved surfaces. Exp. Cell Res. 65, 193-201

9. Cukierman, E. et al. (2001) Taking cell-matrix adhesions to the third dimension. Science, 294, 1708-1712

10. Lee, S.J. and Yang, S. (2012) Micro glass ball embedded gels to study cell mechanobiological responses to substrate curvatures. Rev. Sci. Instrum. 83, 094302

11. Frost, A. et al. (2009) The BAR domain superfamily: membranemolding macromolecules. Cell, 137, 191-196

12. Nobes, C.D. and Hall, A. (1995) Rho, Rac, and Cdc42 GTPases regulate the assembly of multimolecular focal complexes associated with actin stress fibers, lamellipodia, and filopodia. Cell, 81, 53-62

13. Olson, M.F. et al. (1995) An essential role for Rho, Rac, and Cdc42 GTPases in cell cycle progression through $\mathrm{G}_{1}$. Science, 269, 1270-1272

14. Zhao, H. et al. (2011) I-BAR domain proteins: linking actin and plasma membrane dynamics. Curr. Opin. Cell Biol. 23, 14-21

15. Patel, A.J. et al. (2001) Lipid and mechano-gated $2 \mathrm{P}$ domain $\mathrm{K}^{+}$ channels. Curr. Opin. Cell Biol. 13, 422-427

16. Park, J.Y. et al. (2009) Study of cellular behaviors on concave and convex microstructures fabricated from elastic PDMS membranes. Lab Chip, 9, 2043-2049

17. Soscia, D.A. et al. (2013) Salivary gland cell differentiation and organization on micropatterned PLGA nanofiber craters. Biomaterials, 34, 6773-6784

18. Dunn, G.A. and Heath, J.P. (1976) A new hypothesis of contact guidance in tissue cells. Exp. Cell Res. 101, 1-14

19. Mathur, A. et al. (2012) The role of feature curvature in contact guidance. Acta Biomater. 8, 2595-2601

20. Pilia, M. et al. (2013) Influence of substrate curvature on osteoblast orientation and extracellular matrix deposition. J. Biol. Eng. 7,23

21. Levina, E.M. et al. (1996) Cylindrical substratum induces differen patterns of actin microfilament bundles in nontransformed and in ras-transformed epitheliocytes. Exp. Cell Res. 229, 159-165

22. Fioretta, E.S. et al. (2014) Differential response of endothelia and endothelial colony forming cells on electrospun scaffolds with distinct microfiber diameters. Biomacromolecules, 15, $821-829$

23. Ye, M. et al. (2014) Brain microvascular endothelial cells resist elongation due to curvature and shear stress. Sci. Rep. 4, 1-6

24. Junkin, M. et al. (2011) Cellular self-organization by autocatalytic alignment feedback. J. Cell Sci. 124, 4213-4220

25. Nelson, W.J. (2009) Remodelling epithelial cell organization: transitions between front-rear and apical basal polarity. Cold Spring Harb. Perspect. Biol. 1, 1-19

26. Cao, X. et al. (2012) Polarized sorting and trafficking in epithelial cells. Cell Res. 22, 793-805

27. James, J. et al. (2008) Subcellular curvature at the perimeter of micropatterned cells influences lamellipodial distribution and cell polarity. Cell Motil. Cytoskeleton, 65, 841-852

28. Ferrari, A. et al. (2011) Nanotopographic control of neuronal polarity. Nano Lett. 11, 505-511

29. Rajnicek, A. et al. (1997) Contact guidance of CNS neurites on grooved quartz: influence of groove dimensions, neuronal age and cell type. J. Cell Sci. 110, 2905-2913

30. Lee, M.R. et al. (2010) Direct differentiation of human embryonic stem cells into selective neurons on nanoscale ridge/groove pattern arrays. Biomaterials, 31, 4360-4366

31. Ladoux, B. et al. (2016) Front-rear polarization by mechanical cues: from single cells to tissues. Trends Cell Biol. 26, 420-433

32. Parker, K.K. et al. (2002) Directional control of lamellipodia extension by constraining cell shape and orienting cell tractional forces. FASEB J. 16, 1195-1204

33. Brock, A. et al. (2003) Geometric determinants of directional cel motility revealed using microcontact printing. Langmuir, 19, $1611-1617$

34. Théry, M. et al. (2005) The extracellular matrix guides the orientation of the cell division axis. Nat. Cell Biol. 7, 947-953

35. Théry, M. et al. (2006) Anisotropy of cell adhesive microenvironment governs cell internal organization and orientation of polarity. Proc. Natl. Acad. Sci. U. S. A. 103, 19771-19776

36. Xi, W. et al. (2017) Emergent patterns of collective cell migration under tubular confinement. Nat. Commun. 8, 1517

37. Liu, T. et al. (2014) Advanced micromachining of concave microwells for long term on-chip culture of multicellular tumor sphe roids. ACS Appl. Mater. Interfaces, 6, 8090-8097

38. Nikkhah, M. et al. (2009) Cytoskeletal role in differential adhesion patterns of normal fibroblasts and breast cancer cells inside silicon microenvironments. Biomed. Microdevices, 11, 585-595

39. Popovic, Z.D. et al. (1988) Technique for monolithic fabrication of microlens arrays. Appl. Opt. 27, 1281-1284 
40. Wagner, B. et al. (1995) Microfabrication of complex surface topographies using grey-tone lithography. Sens. Actuator APhys. 46, 89-94

41. Sun, L. et al. (2016) Independent effects of the chemical and microstructural surface properties of polymer/ceramic composites on proliferation and osteogenic differentiation of human MSCs. Acta Biomater. 42, 364-377

42. Ng, C.K.M. et al. (2012) Fabrication of substrates with curvature for cell cultivation by alpha-particle irradiation and chemical etching of PADC films. Nucl. Instrum. Methods Phys. Res. B, 278, 1519

43. Hoffman, J.M. et al. (2004) Elastomeric molds with tunable microtopography. Adv. Mater. 16, 2201-2206

44. Jeong, G.S. et al. (2012) Meniscus induced self organization of multiple deep concave wells in a microchannel for embryoid bodies generation. Lab Chip, 12, 159-166

45. Jeong. G.S. et al. (2013) Surface tension-mediated, concavemicrowell arrays for large-scale, simultaneous production of homogeneously sized embryoid bodies. Adv. Healthc. Mater. 2. 119-125

46. Fiddes, L.K. et al. (2010) A circular cross-section PDMS microfluidics system for replication of cardiovascular flow conditions. Biomaterials, 31, 3459-3464

47. Chao, S. et al. (2007) Rapid fabrication of microchannels using microscale plasma activated templating (microPLAT) generated water molds. Lab Chip, 7, 641-643

48. Park, J.Y. et al. (2009) Ice-lithographic fabrication of concave microwells and a microfluidic network. Biomed. Microdevices, $11,129-133$

49. Truckenmüller, R. et al. (2011) Thermoforming of film-based biomedical microdevices. Adv. Mater. 23, 1311-1329

50. Nguyen, A.K. and Narayan, R.J. (2017) Two-photon polymerization for biological applications. Mater. Today, 20, 314-322

51. Giselbrecht, S. et al. (2011) Closer to nature-bio-inspired patterns by transforming latent lithographic images. Adv. Mater. 23, 48734879

52. Truckenmuller, R. et al. (2012) Fabrication of cell container arrays with overlaid surface topographies. Biomed. Microdevices, 14, 95-107

53. Waterkotte, B. et al. (2014) Biofunctional micropatterning of thermoformed 3D substrates. Adv. Funct. Mater. 24, 442-450

54. Giselbrecht, S. et al. (2006) 3D tissue culture substrates produced by microthermoforming of pre-processed polymer films. Biomed. Microdevices, 8, 191-199

55. Hebeiss, I. et al. (2012) Novel three-dimensional Boyden chamber system for studying transendothelial transport. Lab Chip, 12 , 829-834

56. Chew, S.Y. et al. (2008) The effect of the alignment of electrospun fibrous scaffolds on Schwann cell maturation. Biomaterials, 29, 653-661

57. Hwang, C.M. et al. (2009) Controlled cellular orientation on PLGA microfibers with defined diameters. Biomed. Microdevices, 11, 739-746

58. Smeal, R.M. et al. (2005) Substrate curvature influences the direction of nerve outgrowth. Ann. Biomed. Eng. 33, 376-382

59. Yevick, H.G. et al. (2015) Architecture and migration of an epithelium on a cylindrical wire. Proc. Natl. Acad. Sci. U. S. A. 112, 5944-5949

60. Unger, R.E. et al. (2005) Growth of human cells on polyethersulfone (PES) hollow fiber membranes. Biomaterials, 26, 1877-1884

61. Lee, S.J. and Yang, S. (2017) Substrate curvature restricts spreading and induces differentiation of human mesenchymal stem cells. Biotechnol. J. 12, 1700360

62. Smith, E.J. et al. (2012) Lab-in-a-tube: ultracompact components for on-chip capture and detection of individual micro-/nanoorganisms. Lab Chip, 12, 1917-1931

63. Lee, G.H. et al. (2016) Magnetic force-assisted self-locking metallic bead array for fabrication of diverse concave microwell geometries. Lab Chip, 16, 3565-3575
64. Costa, P.F. et al. (2017) Mimicking arterial thrombosis in a 3D printed microfluidic: in vitro vascular model based on computed tomography angiography data. Lab Chip, 17, 27852792

65. Bade, N.D. et al. (2018) Gaussian curvature directs stress fiber orientation and cell migration. Biophys. J. 114, 1467-1476

66. Song, K.H. et al. (2015) Sinusoidal wavy surfaces for curvatureguided migration of Tlymphocytes. Biomaterials, 51, 151-160

67. Pieuchot, L. et al. (2018) Curvotaxis directs cell migration through cell-scale curvature landscapes. Nat. Commun. 9, 3995

68. Yip, A.K. et al. (2018) Cell-cell adhesion and cortical actin bending govern cell elongation on negatively curved substrates. Biophys. J. 114, 1707-1717

69. Yamashita, T. et al. (2016) Cell sheet mechanics: how geometrica constraints induce the detachment of cell sheets from concave surfaces. Acta Biomater. 45, 85-97

70. Wan, H. et al. (2000) Tight junction properties of the immortalized human bronchial epithelial cell lines Calu-3 and 16HBE140-. Eur. Respir. J. 15, 1058-1068

71. Seefried, L. et al. (2010) A small scale cell culture system to analyze mechanobiology using reporter gene constructs and polyurethane dishes. Eur. Cells Mater. 20, 344-355

72. Lamar, J.M. et al. (2012) The Hippo pathway target, YAP, promotes metastasis through its TEAD-interaction domain. Proc. Natl. Acad. Sci. U. S. A. 109, E2441-E2450

73. Unadkat, H.V. et al. (2011) An algorithm-based topographical biomaterials library to instruct cell fate. Proc. Natl. Acad. Sci. U. S. A. $108,16565-16570$

74. Werner, M. et al. (2017) Surface curvature differentially regulates stem cell migration and differentiation via altered attachment morphology and nuclear deformation. Adv. Sci. 4, 1-11

75. Sun, B. and Lam, R.H.W. (2016) Influence of micro-scale substrate curvature on subcellular behaviors of vascular cells. IEEE 16th International Conference on Nanotechnology (IEEE-NANO), 339-342

76. Pietsch, M. et al. (2017) Spiral form of the human cochlea results from spatial constraints. Sci. Rep. 7, 1-11

77. Jian, S. et al. (2018) Nanofibers with diameter below one nanometer from electrospinning. RSC Adv. 8, 4794-4802

78. Frame, M.D. and Sarelius, I.H. (2000) Flow-induced cytoskeletal changes in endothelial cells growing on curved surfaces. Microcirculation, 7, 419-427

79. Rumpler, M. et al. (2008) The effect of geometry on three-dimensional tissue growth. J. R. Soc. Interface, 5, 1173-1180

80. Douglass, K.M. et al. (2013) Measuring anisotropic cell motility on curved substrates. J. Biophotonics, 6, 387-392

81. Rovensky, Y.A. and Samoilov, V.I. (1994) Morphogenetic response of cultured normal and transformed fibroblasts, and epitheliocytes, to a cylindrical substratum surface. Possible role for the actin filament bundle pattern. J. Cell Sci. 107, 1255-1263

82. McMahon, H.T. and Gallop, J.L. (2005) Membrane curvature and mechanisms of dynamic cell membrane remodelling. Nature, 438, 590-596

83. Helfrich, W. (1973) Elastic properties of lipid bilayers: theory and possible experiments. Z. Naturforsch. C, 28, 693-703

84. Harkewicz, R. and Dennis, E.A. (2011) Applications of mass spectrometry to lipids and membranes. Annu. Rev. Biochem. $80,301-325$

85. Zimmerberg, J. and Kozlov, M.M. (2006) How proteins produce cellular membrane curvature. Nat. Rev. Mol. Cell Biol. 7, 9-19

86. Habermann, B. (2004) The BAR-domain family of proteins: a case of bending and binding? EMBO Rep. 5, 250-255

87. Linkner, J. et al. (2014) The inverse BAR domain protein IBARa drives membrane remodeling to control osmoregulation, phagocytosis and cytokinesis. J. Cell Sci. 127, 1279-1292

88. van der Flier, L.G. and Clevers, H.C. (2009) Stem cells, selfrenewal, and differentiation in the intestinal epithelium. Annu. Rev. Physiol. 71, 241-260 
89. Krausova, M. and Korinek, V. (2014) Wnt signaling in adult intestinal stem cells and cancer. Cell. Signal. 26, 570-579

90. Yu, F.X. and Guan, K.L. (2013) The Hippo pathway: regulators and regulations. Genes Dev. 27, 355-371

91. Halder, G. etal. (2012) Transduction of mechanical and cytoskeletal cues by YAP and TAZ. Nat. Rev. Mol. Cell Biol. 13, 591-600

92. Low, B.C. et al. (2014) YAP/TAZ as mechanosensors and mechanotransducers in regulating organ size and tumor growth. FEBS Lett. 588, 2663-2670

93. Dupont, S. et al. (2011) Role of YAP/TAZ in mechanotransduction. Nature, 474, 179-183

94. Oka, T. et al. (2012) Opposing roles of angiomotin-like-1 and zona occludens-2 on pro-apoptotic function of YAP. Oncogene, 31 128-134
95. Oka, T. et al. (2010) Functional complexes between YAP2 and ZO-2 are PDZ domain-dependent, and regulate YAP2 nuclear localization and signalling. Biochem. J. 432, 461-472

96. Aragona, M. et al. (2013) A mechanical checkpoint controls multicellular growth through YAP/TAZ regulation by actin-processing factors. Cell, 154, 1047-1059

97. Liss, A.R. (1988) Tissue engineering. In Proceedings of UCLA Symposia on Molecular and Cellular Biology. new series, Granlibakken, Lake Tahoe, California (vol. 107) (Skalak, R. and Fox, C. F., eds.), February 26-29

98. Weibel, E.R. (2013) It takes more than cells to make a good lung Am. J. Respir. Crit. Care Med. 187, 342-346 